UDC 332.3:349.415

\title{
LEGISLATIVE PROVISION OF REGULATION IN THE FIELD OF LAND USE AND PROTECTION
}

\author{
Dorosh Y., Doctor of Economics, Professor, Corresponding Member of NAAS, \\ Land Management Institute of NAAS of Ukraine, \\ e-mail:landukrainenaas@gmail.com \\ Barvinskyi A., Ph.D. in Agricultural Sciences, \\ Land Management Institute of NAAS of Ukraine, \\ e-mail:barv@ukr.net
} \begin{abstract}
National Aviation University, e-mail: iryna.novakovska@npp.nau/edu.ua

Avramchuk B., Ph.D. in Economic Sciences, Land Management Institute of NAAS of Ukraine, e-mail: avramchuk.bogdan@gmail.com

Stetsiuk M., Ph.D. in Economic Sciences, National Aviation University, e-mail:19570511@ukr.net
\end{abstract}

Novakovska I., Doctor of Economics, Associate Professor, Corresponding Member of NAAS,

The current state of legislative support in the field of land use and protection is analyzed. It is established that the legal framework in this area, especially with regard to the powers of executive authorities and local governments, is characterized by a lack of system, clarity and specificity, which is a significant obstacle to the practical implementation of land protection measures.

It is proved that the improvement of legislative support in the research area should be carried out by systematizing the relevant powers of executive authorities and local governments, filling existing gaps, eliminating unnecessary layers and conflicts in laws and regulations.

The need to eliminate the dispersion and duplication of powers of executive authorities and local governments in the field of land use and protection to improve the efficiency of their activities in this area by making appropriate changes and additions to legislation. To this end, it is proposed to concentrate norms on similar powers of different ministries, services, inspections, local governments and local administrations in this area in one legislative act, and to strengthen state control over land use and protection, regardless of category and form of ownership, to restore the State Land Inspectorate. Ukraine with the granting of appropriate powers.

Key words: land use and protection, legislative acts, powers of executive bodies and local self-government. 
Problem statement. The legal framework that defines the powers of executive authorities and local governments in the field of land use and protection is characterized by a lack of systemic nature, which significantly reduces the level of effectiveness of the practical activities of these bodies in this area. This applies to the transformation processes that took place in the field of land relations not "by the reformation, which provided for gradual institutional development..., and revolutionary...", which requires "urgent creation of new institutions and the formation of a modern institutional social environment" [4, p. 21]. The latter, combined with insufficient funding for land protection measures, self-removal of the state from the performance of control functions has led to a deterioration of the environmental situation in the country as a whole and in rural areas - in particular.

Negative processes in the land protection sphere became especially acute during the period of cardinal transformation of land relations, which was accompanied by processes of decentralization of power, formation of united territorial communities, delimitation of state and communal lands, etc. Therefore, solving this problem requires improving the legal framework of the state in relation to the powers of executive authorities and local governments in the field of land use and protection in accordance with the strategic objectives of land reform in Ukraine. This approach will "...eliminate the institutional conflict of interest, which is one of the main causes of inefficient land use management" [5, p. 103].

Analysis of recent research and publications. Problems of legislative support in the field of land use and protection in Ukraine and abroad are devoted to the works of N. Bagay [1], L. Dolmatova [3], O. Zigriy [9], A. Miroshnichenko [11] , G. Shust [22] and others, which emphasizes the need to implement a systematic and comprehensive approach to solving issues of land protection. In the works of O. Dorosh, D. Melnyk [4; 5] and others focus on improving the reform of land management system in the direction of redistribution of management functions between the executive authorities and territorial communities in the field of land relations and land protection. 
According to foreign experience, each country is characterized by its own system of land legislation: in countries such as Belarus, Lithuania, Moldova legislation forms an independent system, and in France, Germany, USA land law is part of various branches of law (agricultural, civil, criminal, etc.). ) [11]. But there is a common understanding that to ensure the preservation and reproduction of land resources requires a combination of interest in this direct business entities on the land and state control over the process of land use. Therefore, developed economies provide some freedom to land owners and users, reserving the right to manage and control (supervise) land use and protection.

In particular, in Germany, the legislation prohibits the shredding of forest and agricultural areas, their alienation and change the permitted method of use [2]. Also under strict control by the state is a change in the permitted use of land in England [10]. In the United States, the system of legislation limits the reorientation of agricultural land to other categories [2]. Even in countries with free circulation of land: Canada, Finland, Switzerland, etc., state or municipal land ownership dominates, and land for use is provided under a lease agreement, which allows municipalities to control their use [3].

Strengthening state control over the use and protection of agricultural land as a special category, especially in the context of economic efficiency, in European countries has led to the transfer of powers to dispose of them to specially authorized bodies such as the Agency for Land Management and Regional Development (France), Agricultural Real Estate Agency (Poland), Land Privatization Agency (Germany), State Territorial Agency (Romania), etc.

In general, central government bodies that implement state land policy are more likely to be entrusted with general organizational functions to create appropriate conditions for the efficient use and protection of land resources, highly productive agricultural production, and the functioning of a civilized land market. Execution of specific tasks in the land sphere is carried out by separate specialized, mainly state institutions, which are responsible for monitoring compliance with current legislation in the field of use and protection of land resources and bringing perpetrators to justice 
in case of violations [22]. In particular, the right to prosecute offenders in the field of land use and protection is vested in the Inspectorate for Environmental Protection in Moldova, the Federal Service for Nature Protection in Germany. In some countries, in particular Belarus [20], Kazakhstan [7], etc., cases of administrative offenses in the field of land use and protection are also considered by the highest governing bodies, in particular, the relevant ministries or departments.

Thus, the analysis of foreign and domestic publications convincingly shows the need for integrated, systematic approaches to improve the legislative framework for regulation in the field of land use and protection.

The purpose of the article is to analyze the legislative support for regulation in the field of land use and protection in Ukraine and justify ways to improve it.

Main research material. According to the first part of Article 5 of the Law "On Land Protection" "regulation in the field of land protection is carried out by the Verkhovna Rada of Ukraine, the Verkhovna Rada of the Autonomous Republic of Crimea, the Cabinet of Ministers of Ukraine, the Council of Ministers of the Autonomous Republic of Crimea, local governments, authorized central executive bodies within the powers established by law" [18].

The powers of executive authorities and local governments in the field of land use and protection are defined by the Land Code of Ukraine (LCU) and the Laws of Ukraine: "On Land Protection", "On State Control over Land Use and Protection", "On Land Management", "On environmental protection", "On land reclamation", etc. However, despite the relatively high level of legislation in this area (in quantitative terms), it was not possible to ensure that the full range of legal norms was taken into account for proper management decisions aimed at the rational use and protection of land. These laws create only the basis for the formation of a holistic systematized array of legislation in the field of land relations in general and the field of land use and protection - in particular. An example of this is the Law of Ukraine "On Land Protection", which contains about 20 reference norms and provides for the development of more than 10 regulations, the vast majority of which have not yet been adopted. This creates the preconditions for the emergence of an excessive 
number of land protection regulations, which will have a negative impact on the effectiveness of legal regulation of public relations in the field of land use and protection [1].

The powers of executive bodies and local self-government in the field of land use and protection can be divided into 3 groups:

1) planning (development and implementation of the National Program of Land Use and Protection) (Cabinet of Ministers of Ukraine (CMU), central executive bodies (CEB), local state administrations); development and implementation of regional programs of land use and protection, regional councils, district councils, local state administrations), development and implementation of targeted programs and documentation on land management for land protection (village, settlement councils);

2) organization (coordination of the activities of executive bodies (CMU); organization of land management (district councils); monitoring of lands (CEB));

3) control (state (CEB, local state administrations); self-governing (regional, district, village, settlement councils)).

However, the analysis of the legislative provision of the powers of these bodies of state power and local self-government shows a lack of specification regarding the definition of their areas of activity and duplication of norms enshrined in various legislative acts. In particular, according to the first part of Article 6 of the Land Code of Ukraine (LCU), the powers of the Verkhovna Rada of Ukraine in the field of land relations include: determining the principles of state policy in the field of land use and protection (paragraph "b"); approval of national programs for land use and protection (paragraph "c") "[8]. In addition to these two norms, the powers of the Verkhovna Rada of Ukraine in the field of land protection Article 6 of the Law "On Land Protection" includes "resolution of other issues in the field of land protection in accordance with the Constitution of Ukraine" [18]. The powers of the Verkhovna Rada of Ukraine are identical, but already in the field of land management, enshrined in Article 9 (paragraph "a" and "c") of the Law "On Land Management" [16]. Similarly, the powers of oblast, rayon, village and settlement councils are determined 
by the provisions of Articles 8, 10 and 12 of the Land Code, Articles 8, 10 and 12 of the Law on Land Protection, Articles 15, 17 and 19 of the Law on Land Management. The same applies to the powers of executive bodies in the field of land use and protection.

At the same time, the powers of executive authorities and local governments related to one area of regulation of land relations (land use and protection) are considered in different areas depending on the subject of the legislation: in the field of land relations in the Land Code, in land management in the Law "On land management ", in the field of land protection in the Law" On land protection ", etc. All this complicates the implementation of these laws in the practice of relevant bodies in the study area.

The current land legislation also lacks clarity regarding the division of functional responsibilities between some specially authorized central executive bodies in the field of land use and protection. Thus, according to Part 3 of Article 5 of the Law "On State Control over Land Use and Protection" "Monitoring of soil fertility and agrochemical certification of agricultural land is carried out by the central executive body for agricultural policy", and in accordance with paragraph 5 of Article 8 of the same Law "Monitoring of soil fertility and agrochemical certification of agricultural land" belongs to the "Powers of the central executive body that implements state policy in the field of land relations" [13].

In addition, according to Article 19 of the Law "On Land Protection" "the central executive body that implements state policy on state supervision (control) in the field of environmental protection", the state monitors compliance with the law only on land protection, and according to Article 171 of the same Law, the powers of the said CEB include "state supervision (control) over compliance with the legislation on land use and protection" [18].

According to the first part of Article 19 of the Law "On Land Protection" "State control over the use and protection of land is exercised by the central executive body implementing state policy in the field of land relations", and according to part four of the same Article "Central Executive Body, which implements the state policy in the 
field of land relations, monitors soil fertility and agrochemical certification of agricultural land" [18]. Since the monitoring of soil fertility and agrochemical certification of agricultural land is part of state control over the use and protection of land in general, the feasibility of the existence of Part 4 in this Article is questionable.

In this context, it should be noted that currently the powers of the executive body implementing state policy in the field of land relations are exercised by the State Service of Ukraine for Geodesy, Cartography and Cadastre (State Geocadastre), because in accordance with paragraph 1 of the Cabinet of Ministers Of Ukraine on Geodesy, Cartography and Cadastre” dated January 14, 2015 №15 with changes made in accordance with the Resolution of the Cabinet of Ministers of July 22, 2016. №482 "The State Service of Ukraine for Geodesy, Cartography and Cadastre (Gosgeokadastr) is a central executive body, whose activities are directed and coordinated by the Cabinet of Ministers of Ukraine through the Minister of Agrarian Policy and Food and which implements state policy in the field of topographic, geodetic and cartographic activities, land relations, land management, in the field of State Land Cadastre, state supervision (control) in the agro-industrial complex in terms of compliance with land legislation, use and protection of land of all categories and forms of ownership, soil fertility" [14].

In addition, in accordance with paragraph 7 of part 2 of Article 14 of the Law "On Land Reclamation" "the powers of the central executive body implementing state policy in the field of land relations on land reclamation include: including the resolution of other issues related to the use of reclaimed lands, within the powers defined by law and assigned to him by the President of Ukraine" [17], which carries the risk of corruption in the exercise of the powers of this executive body, as the content of the latter is not clearly defined.

Taking into account the norm of Part 2 of Article 17 of the Law "On Central Executive Bodies": "If most of the functions of the central executive body are functions of providing administrative services to individuals and legal entities, the central executive body is formed as a service" [19], the main function The State Geocadastre, established as a service, should provide appropriate administrative 
services. At the same time, the powers of the State Geocadastre also include functions related to the disposal of state property belonging to the sphere of its management (these are the functions of the agency) and control and supervisory functions (these are the functions of inspection) [14].

In addition, according to paragraph 3 of the "Regulations on the State Service of Ukraine for Geodesy, Cartography and Cadastre" among the main tasks of this CEB in the first position are the functions of supervision (control) (subparagraph 1), and only then the provision of administrative services by law in the relevant field" (subparagraph 2) [14]. This is also confirmed by information from the official website of the State Geocadastre, which states that it is "the central executive body that implements state policy in the field of state supervision (control) in the agroindustrial complex in terms of compliance with land legislation, land use and protection of all categories and forms of ownership, soil fertility" [21]. Therefore, the above indicates the inconsistency of the form of content and according to the stated tasks, this CEB should have the status not of service but of inspection.

Analysis of the tasks of the State Geocadastre defined by its Regulations shows that the functions of supervision (control) in the field of land use and protection should be considered ancillary, and the function of "drawing up protocols and reviewing cases of administrative offenses, imposing administrative penalties" [14] in the same field - generally "inexpedient", especially considering that such powers are amended by the Regulations on the State Geocadastre one and a half years after the formation of the CEB in accordance with the Resolution of the Cabinet of Ministers №482 of 22.07.2016, of course, will have a negative impact on the implementation of its functions: failure to perform them at all or improper performance, resulting in a violation of the rights and interests of both the individual and the state as a whole by causing damage to protected objects.

In addition, the addition to the list of tasks of the State Geocadastre makes it impossible to comply with the principle of "avoiding the combination of diametrically opposed powers in the activities of one state body and duplication of powers" enshrined in the Law "On Central Executive Bodies" offenses, imposition of 
administrative penalties in cases provided by law in the field of land protection are also provided by the State Ecological Inspection [15]. Therefore, there are currently two CEBs, which have the right to draw up protocols on administrative offenses in the field of land use and protection and to consider relevant cases, which confirms the existence of duplication of powers.

It is also possible to consider a formal division of powers of these CEBs to exercise state control in the field of land use and protection, defined by Article 19 of the Law "On Land Protection", as the concepts of "land use and protection" and "compliance with land protection legislation" are interrelated. In addition, noncompliance with the provisions of the Final Provisions of this Law does not allow these CEBs to perform their functions properly. Thus, according to sub-paragraph 2 of paragraph 4 "Regulations on the State Ecological Inspectorate of Ukraine" approved by the Resolution of the Cabinet of Ministers of Ukraine of April 19, 2017 № 275, this CEB “carries out state supervision (control) over compliance with central executive bodies and their territorial bodies, local executive authorities, local governments in terms of exercising the powers delegated to them by executive authorities, enterprises, institutions and organizations regardless of ownership and management, citizens of Ukraine, foreigners and stateless persons, as well as nonresident legal entities: b) on protection of lands, subsoil, in particular on: compliance with environmental standards for land use and protection" [15], but such standards, defined by Article 30 of the Law" On Land Protection "are still in the status of recommendations of research institutions and are not enshrined in the relevant regulations.

Duplicate powers of CEBs in the field of land use and protection are also found in the Law on Land Reclamation. Thus, in accordance with paragraph 4 of part 8 of Article 14 of this Law "To the powers of the central executive body implementing state policy on state supervision (control) in the field of environmental protection, rational use, reproduction and protection of natural resources in land reclamation, includes: in particular, the implementation of state supervision (control) over the reclamation of irrigated and drained lands..."; and in accordance with paragraph 5 
of part 4 of the same Article "the powers of the central executive body that ensures the formation of state agricultural policy in the field of land reclamation include: including ensuring state control over the efficiency of agricultural use of reclaimed land" [17]. In addition, the latter provision contradicts Article 19 of the Law "On Land Protection", according to Part 4 of which the authority to "monitor soil fertility and agrochemical certification of agricultural land" is vested in the CEB, which implements state policy in the field of land relations [18].

In view of this, it seems logical to consolidate the function of state control over the use and protection of all categories of land, regardless of ownership of land (including compliance with land protection legislation) by the State Land Inspectorate, the restoration of which is becoming increasingly important. "Opening" the market circulation of agricultural land.

It should be borne in mind that a clear mechanism for implementing the specific powers of the executive bodies of village councils, enshrined in Article 61 of the Law "On state control over the use and protection of land" on: "state control over the use and protection of land, namely: implementation by landowners and users of a set of necessary measures to protect land from overgrowing with weeds and shrubs; compliance with the mode of operation of anti-erosion, hydraulic structures, as well as the requirements of the legislation on the preservation of protective plantings and boundary markers; compliance by landowners and land users with the requirements for the use of land for its intended purpose, location, design, construction, commissioning of facilities that adversely affect the condition of land, operation, preservation of anti-erosion hydraulic structures, protective plantations" [13], does not currently exist, which will certainly lead to inconsistencies in the actions of state inspectors of executive committees of village, settlement councils and departments for control over the use and protection of lands of the Main Departments of the State Geocadastre in the regions.

Conclusions. The legislative framework in the field of land use and protection, formed during the period of radical reform of land relations, does not provide proper regulation of public relations in this area, including the powers of executive 
authorities and local governments due to lack of system, clarity, specificity and legislation. bylaws developed on their basis.

Improvement of legislative support in the field of land use and protection should be carried out in the direction of filling existing gaps, eliminating unnecessary layers and conflicts in the relevant regulations, systematization of powers of executive authorities and local governments, as defined by numerous laws and regulations.

This requires:

1) in order to eliminate duplication of similar powers of executive bodies and local governments in the field of land use and protection, defined by different laws, to concentrate them in one legislative act: either the Land Code or a special law on defining the powers of these bodies;

2) to restore the State Land Inspectorate of Ukraine as a CEB, subordinated directly to the Cabinet of Ministers without coordination of its activities by any relevant ministry;

3) to carry out full delimitation of powers of executive bodies and local selfgovernment bodies in the field of land use and protection;

4) to introduce in the legal plane of the land management sphere the provision of "scientific and legal opinion" as a tool for solving problematic issues in the field of land protection [6].

\section{References}

1. Bahai N.O. (2008) Zakonodavstvo Ukrainy pro okhoronu zemel: problemy rozvytku [Legislation of Ukraine on land protection: problems of development]. Available at: http://www.irbis-nbuv.gov.ua/.

2. Volkov S.N. (2005) Zemleustroistvo. T. 7. Zemleustroistvo za rubezhom [Land management. T. 7. Land management abroad]. Moscow: Kolos, 408.

3. Dolmatova L.H. (2011) Osnovy hosudarstvennoho rehulyrovanyia v oblasti ispolzovanyia $\mathrm{i}$ okhrany zemelnykh resursov $\mathrm{v}$ sovremennykh uslovyiakh [Fundamentals of state regulation in the field of use and protection of land resources in modern conditions]. Available at: http://www.ivdon.ru/ru/magazine/archive/n2y2011/440. 
4. Dorosh O.S. (2016) Reformuvannia systemy upravlinnia zemelnymy resursamy $\mathrm{v}$ umovakh detsentralizatsii vlady [Reforming the land resources management system in terms of decentralization of power] Zemleustrii, kadastr i monitorynh zemel, № 1-2, 16 - 25 .

5. Dorosh O.S. (2017) Kontsept rozpodilu funktsii upravlinnia zemlekorystuvanniam v konteksti rozvytku terytorialnykh hromad [The concept of distribution of land management functions in the context of territorial community development]. Zbalansovane pryrodokorystuvannia, № 3, 97 - 107.

6. Dorosh Y.M. (2019) Naukovo-pravovyi vysnovok - instrument rozviazannia problemnykh pytan $\mathrm{v}$ pravovii ploshchyni zemlevporiadnoi sfery [Scientific and legal conclusion - a tool for solving problematic issues in the legal plane of the land management sphere]. Zemleustrii, kadastr i monitorynh zemel, № 2, 8692.

7. Land Code of the Republic of Kazakhstan (2003). Available at: http://base.spinform.ru/show_doc.fwx?rgn=3672.

8. The Verkhovna Rada of Ukraine (2001), The Law of Ukraine "Land Code of Ukraine". Available at: http://zakon4.rada.gov.ua/laws/show/2768-14.

9. Zyhrii O. (2017) Orhanizatsiino-pravovyi aspekt vykorystannia ta okhorony zemel [Organizational and legal aspect of land use and protection]. Aktualni problemy pravoznavstva., 1(9), 70-74.

10. Kuibida V.S. (2009) Rehionalnyi rozvytok ta prostorove planuvannia terytorii: dosvid Ukrainy ta inshykh derzhav-chleniv Rady Yevropy [Regional development and spatial planning of territories: experience of Ukraine and other member states of the Council of Europe]. Kyiv: "Kramar", 170.

11. Miroshnychenko A.M. (2009) Zemelne pravo Ukrainy: pidruchnyk [Land law of Ukraine: a textbook]. Kyiv: Aleuta; KNT; TsUL, 712.

12. The Verkhovna Rada of Ukraine (2021), The Law of Ukraine "On Amendments to Certain Legislative Acts of Ukraine Concerning the Improvement of the Management and Deregulation System in the Sphere of Land Relations". Available at: https://zakon. rada.gov.ua/laws/show/1423-20\#top.

13. The Verkhovna Rada of Ukraine (2003), The Law of Ukraine "On state 
control over the use and protection of land". Available at: http://zakon1.rada.gov.ua/laws /show/ 963-15.

14. The Cabinet of Ministry of Ukraine (2015), Regulation "On the State Service of Ukraine for Geodesy, Cartography and Cadastre". Ofitsiinyi visnyk Ukrainy, № 7, 79 .

15. The Cabinet of Ministry of Ukraine (2017), Regulation “On approval of the Regulation on the State Ecological Inspectorate of Ukraine". Available at: https://zakon.rada.gov.ua/laws/show/275-2017-\%D0\%BF\#top.

16. The Verkhovna Rada of Ukraine (2003), The Law of Ukraine “On land management". Available at: http://zakon2.rada.gov.ua/laws/show/858-15.

17. The Verkhovna Rada of Ukraine (2000), The Law of Ukraine "On land reclamation”. Available at: https://zakon.rada.gov.ua/laws/show/1389-14\#top.

18. The Verkhovna Rada of Ukraine (2003), The Law of Ukraine "On land protection". Available at: http://zakon1.rada.gov.ua/laws/show/962-15.

19. The Verkhovna Rada of Ukraine (2011), The Law of Ukraine “On central executive bodies”. Vidomosti Verkhovnoi Rady Ukrainy, № 38, 385.

20. Procedural and Executive Code of the Republic of Belarus on Administrative Offenses (2006). Available at: http://base.spinform.ru/show_doc.fwx?rgn=14894.

21. Website of the State Service of Ukraine for Geodesy, Cartography and Cadastre (2021). Available at: http://land.gov.ua.

22. Shust H.P. (2018) Pravova okhorona zemel ta yii funktsii [Legal protection of lands and its functions]. Science Review: Open Access Peer-reviewed Journal. Warsaw, Poland, № 3, Vol. 8, March, 69-74.

$$
* * *
$$

Дорош Й.М., Барвінський А.В., Новаковська І.О., Аврамчук Б.О., Стецюк М.П.

ЗАКОНОДАВЧЕ ЗАБЕЗПЕЧЕННЯ РЕГУЛЮВАННЯ В ГАЛУЗІ ВИКОРИСТАННЯ ТА ОХОРОНИ ЗЕМЕЛЬ 
Проаналізовано сучасний стан законодавчого забезпечення регулювання в галузі використання та охорони земель. Встановлено, щяо нормативно-правова база в цій галузі, особливо стосовно повноважень органів виконавчої влади $i$ місиевого самоврядування, характеризується відсутністю системності, чіткості та конкретності, що є суттєвою перепоною на шляху практичної реалізачії землеохоронних заходів.

Доведено, щуо удосконалення законодавчого забезпечення в досліджуваній сфері має здійснюватись шляхом систематизаиії відповідних повноважень органів виконавчої влади і місиевого самоврядування, заповнення існуючих прогалин, усунення зайвих намарувань та колізій в законодавчих та підзаконних актах.

Обгрунтована необхідність усунення розпорошеності та дублювання повноважень органів виконавчої влади та місиевого самоврядування в галузі використання та охорони земель для підвищення ефективності їхньої діяльності в зазначеній сфері шляхом внесення відповідних змін та доповнень до законодавчих актів. Для цзього пропонується норми щодо аналогічних повноважень різних міністерств, служб, інспекцій, органів місиевого самоврядування та місиевих адміністраиій в иүій галузі зосередити в одному законодавчому акті, а для посилення державного контролю за використанням та охороною земель незалежно від категорії та форми власності відновити функиіонування Державної земельної інспекції України з наданням їй відповідних повноважень.

Ключові слова: використання та охорона земель, законодавчі акти, повноваження органів виконавчої влади та місиевого самоврядування.

$$
* * *
$$

Дорош Й.М., Барвинский А.В., Новаковская И.О., Аврамчук Б.О., Стецюк М.П.

ЗАКОНОДАТЕЛЬНОЕ ОБЕСПЕЧЕНИЕ РЕГУЛИРОВАНИЯ В ОБЛАСТИ ИСПОЛЬЗОВАНИЯ И ОХРАНЫ ЗЕМЕЛЬ

Проанализировано современное состояние законодательного обеспечения 
регулирования в области использования и охраны земель. Установлено, что нормативно-правовая база в этой области, особенно в отношении полномочий органов исполнительной власти и местного самоуправления, характеризуется отсутствием системности, четкости и конкретности, что является существенным препятствием на пути практической реализащии землеохранные мероприятий.

Доказано, что усовершенствование законодательного обеспечения в исследуемой сфере должно осуществляться путем систематизации соответствующих полномочий органов исполнительной власти и местного самоуправления, заполнение существующих пробелов, устранение лишних наслоений и коллизий в законодательных и подзаконных актах.

Обоснована необходимость устранения разобщенности и дублирования полномочий органов исполнительной власти и местного самоуправления в области использования и охраны земель для повышения эффективности их деятельности в указанной сфере путем внесения соответствуюших изменений и дополнений в законодательные акты. Для этого предлагается нормы относительно аналогичных полномочий различных министерств, служб, инспекиий, органов местного самоуправления и местных администраций в этой области сосредоточить в одном законодательном акте, а для усиления государственного контроля за использованием и охраной земель независимо от категории и формы собственности восстановить функционирование Государственной земельной инспекиии Украина с предоставлением ей соответствующих полномочий.

Ключевые слова: использование и охрана земель, законодательные акты, полномочия органов исполнительной власти и местного самоуправления. 